\title{
Pengaruh Return On Asset dan Free Cash Flow Terhadap Tingkat Leverage Perusahaan Pada PT. Wijaya Karya Tbk tahun 2013-2017
}

\author{
Ugeng Budi Haryoko ${ }^{1)}$ \& Elisa Melvianti ${ }^{2)}$
}

${ }^{1,2)}$ dosen dan mahasiwa Universitas Pamulang, email : ugengbudiunpam@gmail.com

\section{ARTICLES \\ INFORMATION \\ ABSTRACT}

\section{JURNAL SEKURITAS (Saham, Ekonomi, \\ Keuangandan Investasi) \\ Vol.3, No.1, September 2019 \\ Halaman : $112-121$ \\ () LPPM \& Prodi Manajemen \\ UNVERSITAS PAMULANG \\ ISSN (online) : 2581-2777 ISSN (print) : 2581-2696}

\section{Keyword :}

Return On Asset, Free Cash Flow, Lavarege

Perusahaan

\section{JEL Classification : \\ C31, G10, G29, N65}

\section{Contact Author: \\ PRODI MANAJEMEN UNPAM \\ JL.Surya Kencana No.1 Pamulang \\ Tangerang Selatan-Banten \\ Telp. (021) 7412586, Fax (021) 7412491 Email: \\ jumalfinance.unpam@gmail.com}

sekuritas@unpam.ac.id

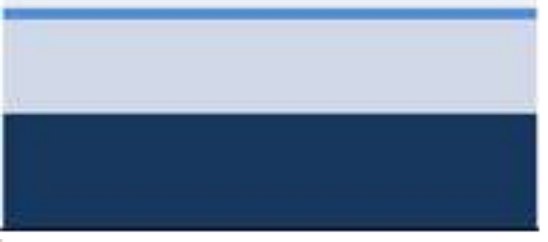

Tujuan penelitian ini adalah untuk mengetahui seberapa besar pengaruh return on asset dan free cash flow terhadap leverage perusahaan pada PT. Wijaya Karya, Tbk pada tahun 2013-2017.

Metode penelitian yang digunakan adalah penelitian deskriptif asosiatif artinya asosiatif

Hasil peneltian menunjukan bahwa terdapat pengaruh Hasil Penelitian Return On Asset (ROA) berpengaruh negative dan signifikan terhadap tingkat leverage perusahaan yang diukur menggunakan Debt to Asset Ratio pada PT.Wijaya Karya, Tbk tahun $2012-2017$. Hal ini dapat dilihat dari hasil $\mathrm{t}$ hitung sebesar $-5,733$ dan nilai signifikan sebesar 0,029 yaitu artinya lebih kecil dari alpha $(0,029<0,05)$ artinya $\left(\mathrm{H}_{0}\right)$ diterima dan $\left(\mathrm{H}_{\mathrm{a}}\right)$ ditolak.dimana terdapat pengaruh negative dan signifikan Return On Asset (ROA) terhadap tingkat leverage perusahaan yang diukur menggunakan Debt to Asset Ratio.

Hasil Penelitian Free Cash Flow (FCF) berpengaruh positif dan signifikan terhadap tingkat leverage perusahaan yang diukur menggunakan Debt to Asset Ratio pada PT.Wijaya Karya, Tbk tahun 2012 - 2017. Hal ini dapat dilihat dari hasil t hitung sebesar 53,676 dan nilai signifikan sebesar 0,000 yaitu artinya lebih kecil dari alpha $(0,000<0,05)$ artinya $\left(\mathrm{H}_{0}\right)$ ditolak dan $\left(\mathrm{H}_{\mathrm{a}}\right)$ diterima.dimana terdapat pengaruh positif dan signifikan Free Cash Flow (FCF) terhadap tingkat leverage perusahaan yang diukur menggunakan Debt to Asset Ratio.Hasil Penelitian Return On Asset (ROA) dan Free Cash Flow (FCF) secara simultan berpengaruh signifikan terhadap tingkat leverage perusahaan yang diukur menggunakan Debt to Asset Ratio pada PT.Wijaya Karya, Tbk tahun 2012 - 2017. Hal ini dapat dilihat dari hasil $F$ hitung sebesar $1,737.876$ dan nilai signifikan sebesar 0,001 yaitu artinya lebih kecil dari alpha $(0,001<0,05)$ artinya $\left(H_{0}\right)$ ditolak dan $\left(H_{a}\right)$ diterima, dimana terdapat pengaruh signifikan Return On Asset (ROA) dan Free Cash Flow (FCF) secara simultan terhadap tingkat leverage perusahaan yang diukur menggunakan Debt to Asset Ratio. Hasil $r=1,000$ yang artinya hubungan antara kedua variable tersebut sangat kuat, dengan $R^{2}=0,999$ atau $99,9 \%$ dan sisanya $0,1 \%$ dipengaruhi faktor lain. 


\section{A. PENDAHULUAN}

\section{Latar Belakang}

Agar perusahaan dapat lebih unggul dalam persaingan yang dihadapi di situasi meningkatnya persaingan dalam era globalisasi saat ini, menuntut setiap perusahaan untuk mampu menyesuaikan dengan keadaan yang terjadi dan melakukan pengelolaan terhadap fungsi-fungsi penting yang ada dalam perusahaan sehingga perusahaan dapat lebih unggul dalam persaingan yang dihadapi. Profitabilitas merupakan kemampuan perusahaan dalam menghasilkan keuntungan atau laba sehingga berpengaruh terhadap leverage perusahaan. Perusahaan yang profitable biasanya menggunakan hutang dalam jumlah sedikit karena perusahaan tersebut menggunakan dana internal untuk keperluan operationalnya. Dalam penelitian ini tingkat profitabilitas diukur menggunakan rasio Return On Assets (ROA) karena ROA bersifat menyeluruh dan komprehensif. Salah satu obyek yang memungkinkan terjadinya perbedaan kepentingan antara manajer dengan pemegang saham tersebut adalah penggunaan free cash flow (aliran kas bebas). Konsep free cash flow merupakan perluasan dari konsep biaya keagenan ke dalam manajemen struktur modal.

Tabel 1.1

Perhitungan Return On Asset Ratio, Free Cash Flow Ratio dan Debt to Asset Ratio.

PT. Wijaya Karya, Tbk.

\begin{tabular}{|c|c|c|c|}
\hline Tahun & ROA (\%) & FCF (\%) & DAR (\%) \\
\hline 2013 & $4.96 \%$ & $-6,86 \%$ & $74.38 \%$ \\
\hline 2014 & $4.72 \%$ & $-14,15 \%$ & $68.72 \%$ \\
\hline 2015 & $3.59 \%$ & $-11,39 \%$ & $72.00 \%$ \\
\hline 2016 & $3.69 \%$ & $-26,84 \%$ & $59.81 \%$ \\
\hline 2017 & $2.97 \%$ & $-16,76 \%$ & $67.97 \%$ \\
\hline
\end{tabular}

Sumber : PT. Wijaya Karya, Tbk, diolah

Dari tabel diatas dapat dilihat bahwa ROA, PCF, DAR PT. Wijaya Karya mengalami fluktuatif, berdasarkan hal tersebut, maka peneliti tertarik untuk melakukan penelitian dengan judul: "Pengaruh Return On Asset dan Free Cash Flow Terhadap Tingkat Leverage Perusahaan Pada PT. Wijaya Karya, Tbk Tahun 2013-2017”.

\section{Perumusan Masalah}

1) Apakah terdapat pengaruh Return On Asset terhadap leverage perusahaan?

2) Apakah terdapat pengaruh Free Cash Flow terhadap leverage perusahaan?

3) Apakah terdapat pengaruh Return On Asset dan Free Cash Flow secara bersama-sama terhadap leverage perusahaan?

\section{B. KAJIAN LITERATUR}

Profitabilitas adalah kemampuan suatu perusahaan dalam memperoleh laba (Munawir, 2002). Dalam hal ini profitabilitas akan menambahkan dana bagi perusahaan yang kemudian akan digunakan untuk investasi maupun laba ditahan. Perusahaan dengan rate of return yang tinggi cenderung menggunakan proporsi hutang yang relatif kecil.

Hal ini disebabkan return yang tinggi akan menyediakan sejumlah dana internal yang relative besar yang diakumulasikan sebagai laba ditahan (Mayangsari, 2001). Hal ini sesuai dengan pecking order theory yang menyatakan bahwa pendanaan internal 
lebih disukai oleh perusahaan. Semakin tinggi porsi dana yang tersedia untuk membiayai operasional perusahaan dan kesempatan investasi yang berasal dari laba ditahan, maka tingkat leverage akan semakin kecil. Dalam penelitian ini tingkat profitabilitas diukur menggunakan rasio Return On Assets (ROA) karena ROA bersifat menyeluruh dan komprehensif.

Free cash flow oleh Jensen (1986) diartikan sebagai cash flow perusahaan yang dihasilkan dalam sebuah periode akuntansi, setelah membayar biaya operasi dan pembiayaan yang diperlukan oleh perusahaan. Cash flow ini mencerminkan keuntungan atau kembalian bagi para penyedia modal, termasuk hutang atau equity. Free cash flow dapat digunakan untuk membayar hutang, membeli kembali saham, membayar dividen atau menahannya untuk kesempatan pertumbuhan di masa depan. Free cash flow memudahkan perusahaan untuk mengukur pertumbuhan bisnis dan pembayaran kepada shareholders.

Perusahaan yang memiliki free cash flow yang tinggi akan memiliki tingkat hutang yang tinggi khususnya ketika perusahaan memiliki investment opportunity set (IOS) rendah. Dengan adanya hutang maka free cash flow yang tersedia akan berkurang, sehingga mengurangi konflik antara manajer dan pemegang saham. Penggunaan hutang memungkinkan manajer untuk secara efektif mengikat janji mereka untuk mengeluarkan arus kas di masa depan guna membayar kewajiban atas biaya pokok dan beban bunga dari hutang. Hutang dapat merupakan suatu substitusi yang efektif untuk dividen yang mampu menekan beban pajak perusahaan. Dengan demikian dapat disimpulkan bahwa free cash flow berpengaruh positif terhadap tingkat Leverage perusahaan.

\section{METODOLOGI PENELITIAN}

Objek dalam penelitian ini PT. Wijaya Karya Tbk . Sampel dalam penelitian ini Sampel yang digunakan dalam penelitian ini adalah laporan posisi keuangan berupa neraca dan laporan laba/rugi PT Wijaya Karya Tbk periode 2013 sampai 2017 . Metode analisis data yang digunakan adalah Analisis Deskriftif dan Analisis verifikatif yang meliputi : uji validitas, uji reabilitas, uji asumsi klasik, uji korelasi, uji koefisien determinasi, analisis regresi berganda, uji parsial, dan uji simultan.

\section{HASIL DAN PEMBAHASAN}

\section{Uji Asumsi Klasik}

Seperti yang sudah dijelaskan pada bab sebelumnya, bahwa untuk mendapatkan ketepatan model yang akan dianalisis perlu dilakukan pengujian atas beberapa persyaratan asumsi klasik yang mendasari model regresi. Uji asumsi klasik ini bertujuan untuk mengetahui dan menguji kelayakan atas model regresi yang digunakan dalam penelitian.

\section{Hasil Uji Normalitas}

Uji normalitas dapat di deteksi dengan melihat penyebaran data (titik) pada sumbu diagonal dari grafik dengan dasar pengambilan keputusan :

1) Jika data menyebar di sekitar garis diagonal dan mengikuti arah garis diagonal, maka regresi memenuhi asumsi normalitas. 
2) Jika data menyebar jauh dari garis diagonal dan/atau tidak mengikuti arag garis diagonal, maka model regresi tidak memenuhi syarat asumsi normalitas

Grafik dapat dilihat seperti gambar berikut ini:

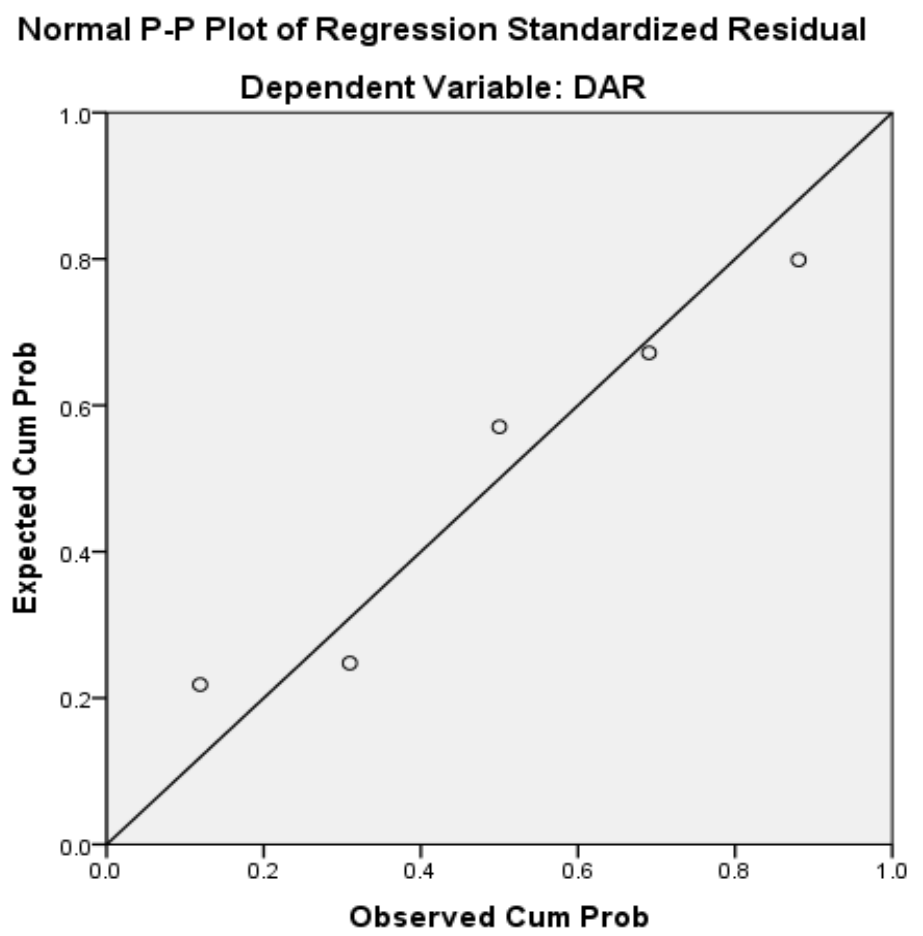

Gambar 1.2

Hasil Uji Normalitas-Normal Probability Plot

Berdasarkan gambar 1.2 grafik P-Plot di atas, terlihat bahwa titik-titik menyebar pada garis diagonal, serta penyebarannya mengikuti arah garis diagonal tersebut. Maka dapat disimpulkan bahwa model regresi yang di uji adalah layak dipakai untuk penelitian.

\section{Uji Multikolinearitas}

Uji Multikolinearitas bertujuan untuk mengetahui adanya hubungan antara beberapa atau semua variable yang menjelaskan dalam model regresi. Uji multikolinearitas dapat dilakukan dengan melihat nilai VIF (Variance Inflacton Factor) dan nilai Tolerance pada tabel berikut ini:

Tabel 1.2

Uji Multikolinearitas

Coefficients $^{\mathrm{a}}$

\begin{tabular}{|c|c|c|c|c|c|c|}
\hline \multirow{2}{*}{\multicolumn{2}{|c|}{ Model }} & \multicolumn{2}{|c|}{$\begin{array}{c}\text { Unstandardized } \\
\text { Coefficients }\end{array}$} & \multirow[b]{2}{*}{ Sig. } & \multicolumn{2}{|c|}{ Collinearity Statistics } \\
\hline & & B & Std. Error & & Tolerance & VIF \\
\hline \multirow[t]{3}{*}{1} & (Constant) & .834 & .007 & .000 & & \\
\hline & $\mathrm{ROA}$ & -.748 & .130 & .029 & .750 & 1.334 \\
\hline & FCF & .779 & .015 & .000 & .750 & 1.334 \\
\hline
\end{tabular}

a. Dependent Variable: DAR

Jurnal Sekuritas, Vol.3, No.1, September 2019 
Penilaian multikolinearitas dapat dilakukan dengan tolak ukur:

1) Jika nilai Tolerance lebih besar 0,1 dan VIF (Variance Inflation Factor) lebih kecil dari 10, maka tidak terjadi multikolinearitas.

2) Jika nilai Tolerance lebih kecil dari atau sama dengan 0,1 dan VIF (Variance Inflation Factor) lebih besar dari atau sama dengan 10, maka terjadi multikolinearitas.

Berdasarkan hasil Uji Multikolinearitas pada tabel 1.2, telrihat untuk variable dependen Return On Asset (ROA) nilai VIF berada pada angka $<10$ yaitu 1,334 dan nilai tolerance mendekati 1 yaitu 0,750 .

Sedangkan, untuk variable dependen Free Cash Flow (FCF) nilai VIF berada pada angka $<10$ yaitu 1,334 dan nilai tolerance mendekati 1 yaitu 0,750 .

Jadi dapat disimpulkan dalam penelitian ini, bahwa tidak ada multikolonieritas antar variable independen dalam model regresi.

\section{Uji Heteroskedastisitas}

Dalam penelitian ini, metode yang digunakan untuk menguji heteroskedastisitas ialah uji Glejser. Pengambilan kesimpulan dengan uji Glejser dilakukan dengan criteria sebagai berikut:

1) Jika nilai Sig $\geq 0,05$, maka tidak terjadi heteroskedastisitas.

2) Jika nilai Sig <0,05, maka terjadi heteroskedastisitas.

Tabel 1.3

Uji Heteroskedastisitas

Coefficients $^{\mathrm{a}}$

\begin{tabular}{|l|l|r|r|r|}
\hline \multicolumn{2}{|l|}{ Model } & \multicolumn{2}{|c|}{ Unstandardized Coefficients } & \multirow{2}{*}{ Sig. } \\
\cline { 3 - 4 } & B & Std. Error & .000 \\
\hline 1 & (Constant) & .834 & .007 & .029 \\
\cline { 2 - 5 } & ROA & -.748 & .130 & .000 \\
\cline { 2 - 5 } & FCF & .779 & .015 & \\
\hline
\end{tabular}

Dari tabel 1.3 diatas dapat dilihat bahwa Return On Asset (ROA) dan Free Cash Flow (FCF) memiliki nilai signifikansi lebih kecil sama dengan 0,05, maka dapat disimpulkan bahwa terjadi heteroskedastisitas.

\section{Uji Outokolerasi}

Pada penelitian ini pengujian autokorelasi menggunakan dasarpengambilan keputusan adalah sebagai berikut:

1) Apabila angka $D-W$ di bawah -2 berarti ada autokolerasi positif.

2) Apabila angka D-W diantara -2 sampai +2 berarti tidak ada autokolerasi.

3) Apabila angka $D-W$ di atas +2 berarti ada autokolerasi negative.

Tabel 1.4

Uji Outokolerasi

Model Summary ${ }^{\text {b }}$

\begin{tabular}{|c|c|c|c|c|c|}
\hline Model & $R$ & R Square & $\begin{array}{c}\text { Adjusted R } \\
\text { Square }\end{array}$ & $\begin{array}{c}\text { Std. Error of the } \\
\text { Estimate }\end{array}$ & Durbin-Watson \\
\hline
\end{tabular}




\begin{tabular}{|l|l|l|l|l|l|}
\hline 1 & $1.000^{\mathrm{a}}$ & .999 & .999 & .0018779 & 2.347 \\
\hline
\end{tabular}

Dari tabel 1.4 diatas didapatkan nilai Durbin Watson (D-W Hitung) sebesar 2,374 atau 2. Berdasarkan criteria yang telah ditentukan DW hitung berada diantara $-2 \leq 2 \leq+2$ maka ini berarti tidak terjadi autokolerasi. Sehingga kesimpulannya adalah Uji Autokolerasi terpenuhi.

\section{Uji Hipotesis}

\section{Hasil Uji Regresi Linear Berganda}

Analisis regresi linear berganda digunakan untuk mengetahui adanya pengaruh atau hubungan secara bersama-sama antar variable dependen dengan variable independen. Berikut adalah perhitungan dengan menggunakan SPSS 24 dengan hasil sebagai berikut:

Tabel 1.5

Hasil Uji Regresi Linear Berganda Coefficients $^{\mathrm{a}}$

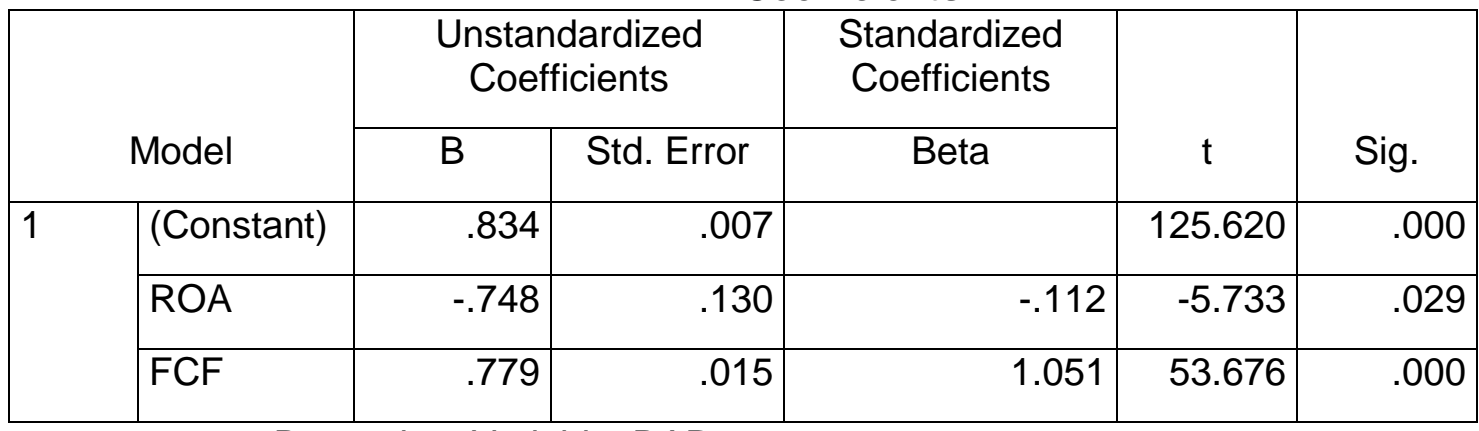

a. Dependent Variable: DAR

Dari tabel 1.5 hasil uji regresi linear berganda di atas, maka diperoleh persamaan regresi sebabagi berikut :

$$
\begin{aligned}
& \mathrm{Y}=0,834+-0,748\left(\mathrm{X}_{1}\right)+0,779\left(\mathrm{X}_{2}\right)+\mathrm{e} \\
& \text { Keterangan : } \\
& \mathrm{Y} \quad=\text { Leverage (Debt To Asset Ratio) } \\
& \alpha \quad=0,834 \text { Konstanta persamaan regresi } \\
& \mathrm{X}_{1} \quad=-0,748 \text { Return On Asset } \\
& \mathrm{X}_{2} \quad=0,779 \text { Free Cash Flow }
\end{aligned}
$$

Dari persamaan diatas, dapat dilihat hubungan antar variable independen yaitu Return On Asset (ROA) dan Free Cash Flow (FCF) dengan variable dependen Debt to Asset Ratio (DAR), maka dapat dijelaskan sebagai berikut :

1) Nilai Konstanta 0,834 dapat diartikan dengan adanya Rerutn On Asset (ROA) dan Free Cash Flow (FCF) memiliki nilai nol (0) maka tingkat leverage perusahaan sebesar 0,834

2) Koefisien regresi dari variable Return On Asset (ROA) sebesar -0,748 mengidentifikasi bahwa setiap 1 Return On Asset yang dihasilkan perusahaan,makaprofitabilitas akan menurun sebesar 0,748.

3) Koefisien regresi dari variable Free Cash Flow (FCF) sebesar 0,779 mengidentifikasi bahwa setiap 1 Free Cash Flow yang dihasilkan

\section{Hasil Uji F (Uji Simultan)} perusahaan,maka akan naik sebesar 0,779.

Uji $\mathrm{F}$ bisa digunakan untuk mengetahui apakah semua variabel independen yang digunakan telah layak atau tidak 
Di bawah ini adalah tabel yang merupakan hasiloutput program SPSS 24 untuk Uji F yaitu sebagai berikut :

Tabel 1.6

Hasil Uji Regresi Linear Berganda ANOVA $^{\mathrm{a}}$

\begin{tabular}{|l|l|r|r|r|r|r|}
\hline \multicolumn{2}{|l|}{ Model } & \multicolumn{1}{c|}{$\begin{array}{c}\text { Sum of } \\
\text { Squares }\end{array}$} & df & $\begin{array}{c}\text { Mean } \\
\text { Square }\end{array}$ & F & Sig. \\
\hline 1 & Regression & .012 & 2 & .006 & 1737.87 & $.001^{\mathrm{b}}$ \\
& Residual & .000 & 2 & .000 & & \\
\cline { 2 - 7 } & Total & .012 & 4 & & & \\
\hline
\end{tabular}

a. Dependent Variable: DAR

b. Predictors: (Constant), FCF, ROA

Sebelum membaca hasil Uji $F$, dalam hal ini harus diketahui terlebih dahulu nilai $F$ tabel yang dapat dilihat pada tabel $F$ yang dapat diperoleh dari buku atau internet. Untuk mencari $F$ tabel menggunakan rumus $d f=n-k$ (variable terikat), maka diperoleh $\mathrm{F}$ tabel sebesar.

Dari tabel 1.6 nilai $F$ hitung sebesar $1,737.876$ dan nilai Ftabel sebesar 19,000 , ini artinya Fhitung < Ftabel. Dan angka signifikan sebesar 0,001 yang artinya lebih kecil dari alpha $(0,001<0,005)$. Berdasarkan keterangan tersebut dapat disimpulkan bahwa Ho diterima dan Ha diterima. Dengan kata lain bahwa secara bersama-sama (simultan) Return On Asset dan Free Cash Flow secara bersama sama berpengaruh signifikan terhadap tingkat Leverage perusahaan (Debt to Asset Ratio).

\section{Koefisien Determinan (Adjusted $\mathbf{R}^{2}$ )}

Uji ini bertujuam untuk mengetahui besarnya variasi variabel dependen yang dapat dijelaskan oleh variasi variabel independen, dan sisanya dijelaskan oleh variabel lain yang dianggap tetap dan tidak dimasukan ke dalam model regresi menurut Ghozali (2016 : 98).

Tabel 1.7

Hasil Koefisien Determinan (Adjusted $\mathbf{R}^{2}$ ) Model Summary ${ }^{\mathrm{b}}$

\begin{tabular}{|l|r|r|r|r|}
\hline Model & R & R Square & Adjusted R Square & Std. Error of the Estimate \\
\hline 1 & $1.000^{\mathrm{a}}$ & .999 & .999 & .0018779 \\
\hline
\end{tabular}

a. Predictors: (Constant), FCF, ROA

b. Dependent Variable: DAR

berdasarkan tabel 1.7 diatas, untuk menentukan besarnya koefisien determinasi antara Return On Asset (ROA) dan Free Cash Flow (FCF) terhadap Debt to Asset Rasio (DAR) yaitu dapat dilihat dari besarnya nilai adjusted $R$ Square yang tedapat pada tabel diatas

yaitu sebesar 0,999 atau menunjukan bahwa kontribusi pengaruh Return On Asset (ROA) dan Free Cash Flow (FCF) sebesar 99,9\% dan berarti ada kontribusi factor lain terhadap tingkat leverage perusahaan sebesar $0,1 \%$. 
Hasil Uji Hipotesis t

Tabel 1.8

Hasil Uji Regresi Linear Berganda Model Summary

\begin{tabular}{|c|c|c|c|c|c|c|}
\hline \multirow{2}{*}{\multicolumn{2}{|c|}{ Model }} & \multicolumn{2}{|c|}{$\begin{array}{l}\text { Unstandardized } \\
\text { Coefficients }\end{array}$} & \multirow{2}{*}{$\begin{array}{c}\text { Standardized } \\
\text { Coefficients } \\
\text { Beta }\end{array}$} & \multirow[b]{2}{*}{$t$} & \multirow[b]{2}{*}{ Sig. } \\
\hline & & B & Std. Error & & & \\
\hline \multirow[t]{3}{*}{1} & (Constant) & .834 & .007 & & 125.620 & .000 \\
\hline & ROA & -.748 & .130 & -.112 & -5.733 & .029 \\
\hline & FCF & .779 & .015 & 1.051 & 53.676 & .000 \\
\hline
\end{tabular}

Berdasarkan tabel 1.8 diatas dan $T$ tabel sebesar 4,303 maka dapat diketahui bahwa :

1) Koefisien variable Return On Asset (ROA) memiliki $T$ hitung sebesar $-5,733$ yaitu artinya $T_{\text {hitung }}<T_{\text {tabel }}(-5,733<4,303)$ dan memiliki nilai signifikan sebesar 0,029 yaitu artinya lebih kecil dari alpha $(0,029<0,05)$. Dari keterangan tersebut dapat disimpulkan bahwa $\mathrm{H}_{10}$ diterima dan $\mathrm{H}_{1 a}$ ditolak yang artinya bahwa Return On Asset (ROA) berpengaruh negative dan signifikan terhadap tingkat leverage perusahaan (Debt to Asset Ratio).

2) Koefisien variable Free Cash Flow (FCF) memiliki T hitung sebesar 53,676 yaitu artinya $T_{\text {hitung }}>T_{\text {tabel }}(53,676>4,303)$ dan memiliki nilai signifikan sebesar 0,000 yaitu artinya lebih kecil dari alpha $(0,000<0,05)$. Dari keterangan tersebut dapat disimpulkan bahwa $\mathrm{H}_{10}$ ditolak dan $\mathrm{H}_{1 \mathrm{a}}$ diterima yang artinya bahwa Free Cash Flow (FCF) berpengaruh negative dan signifikan terhadap tingkat leverage perusahaan (Debt to Asset Ratio).

\section{E. SIMPULAN}

\section{Kesimpulan}

Berdasarkan pembahasan dan hasil penelitian mengenai Pengaruh Return On Asset (ROA) dan Free Cash Flow (FCF) terhadap Tingkat Leverage Perusahaan yang diukur menggunakan Debt to Asset Ratio pada PT.Wijaya Karya, Tbk tahun 2012 - 2017, maka diperoleh kesimpulan sebagai berikut :

1) Hasil Penelitian Return On Asset (ROA) berpengaruh negative dan signifikan terhadap tingkat leverage perusahaan yang diukur menggunakan Debt to Asset Ratio pada PT.Wijaya Karya, Tbk tahun 2012 - 2017. Hal ini dapat dilihat dari hasil t hitung sebesar $-5,733$ dan nilai signifikan sebesar 0,029 yaitu artinya lebih kecil dari alpha $(0,029<0,05)$ artinya $\left(H_{0}\right)$ diterima dan $\left(H_{a}\right)$ ditolak.dimana terdapat pengaruh negative dan signifikan Return On Asset (ROA) terhadap tingkat leverage perusahaan yang diukur menggunakan Debt to Asset Ratio.

2) Hasil Penelitian Free Cash Flow (FCF) berpengaruh positif dan signifikan terhadap tingkat leverage perusahaan yang diukur menggunakan Debt to Asset Ratio pada PT.Wijaya Karya, Tbk tahun 2012 - 2017. Hal ini dapat dilihat dari hasil t hitung sebesar 53,676 dan nilai signifikan sebesar 0,000 yaitu artinya lebih kecil dari alpha $(0,000<0,05)$ artinya $\left(\mathrm{H}_{0}\right)$ ditolak dan $\left(\mathrm{H}_{\mathrm{a}}\right)$ diterima.dimana terdapat pengaruh positif dan signifikan Free Cash Flow (FCF) terhadap tingkat leverage perusahaan yang diukur menggunakan Debt to Asset Ratio.

3) Hasil Penelitian Return On Asset (ROA) dan Free Cash Flow (FCF) secara simultan berpengaruh signifikan terhadap tingkat leverage perusahaan yang diukur 
menggunakan Debt to Asset Ratio pada PT.Wijaya Karya, Tbk tahun $2012-2017$. Hal ini dapat dilihat dari hasil $F$ hitung sebesar 1,737.876 dan nilai signifikan sebesar 0,001 yaitu artinya lebih kecil dari alpha $(0,001<0,05)$ artinya $\left(\mathrm{H}_{0}\right)$ ditolak dan $\left(\mathrm{H}_{\mathrm{a}}\right)$ diterima, dimana terdapat pengaruh signifikan Return On Asset (ROA) dan Free Cash Flow (FCF) secara simultan terhadap tingkat leverage perusahaan yang diukur menggunakan Debt to Asset Ratio. Hasil $r=1,000$ yang artinya hubungan antara kedua variable tersebut sangat kuat, dengan $R^{2}=0,999$ atau $99,9 \%$ dan sisanya $0,1 \%$ dipengaruhi faktor lain.

\section{Saran}

Berdasarkan hasil penelitian dan kesimpulan, maka peneliti memberikan saran sebagai berikut :

1. Disarankan untukpenelitian selanjutnya menggunakan periode tahun pengamatan yang lebih lama dan terbaru. Penambahan jumlah sampel penelitian dengan periode pengamatan yang lebih lama dan terbaru akan memberikan kemungkinan lebih besar dalam memperoleh hasil yang mendekati kondisi sesungguhnya.

2. Variabel-variabel yang memengaruhi tingkat leverage yang memiliki hasil signifikan dalam penelitian ini yaitu Return On Asset (ROA) dan free cash flow (FCF) dapat dijadikan sebagai pertimbangan bagi investor dalam pengambilan keputusan mengenai penggunaan kebijakan utang yang optimal agar tercapai tujuan perusahaan yaitu meningkatkan kesejahteraan pemegang saham. 


\section{DAFTAR PUSTAKA}

Fahmi, Irham, "Analisis Kinerja Keuangan" Cetakan Ketiga Oktober 2014, CV. Alfabeta, Bandung, 2014.

Fahmi, Irham, "Analisis Laporan Keuangan" Cetakan Kelima Desember 2015, CV, Alfabeta, Bandung, 2015.

Fahmi, Irham, "Pengantar Manajemen Keuangan", Cetakan V, ALFABETA CV, Bandung, 2016.

Harjito, Agus dan Martono, "Manajemen Keuangan", Cetakan Kedelapan, Ekonisia, Yogyakarta, 2010.

Hery, “Analisis Laporan Keuangan”, PT. Bumi Aksara, Jakarta, 2012.

Hery, "Analisis Laporan Keuangan-Integrated and Comprehensive Edition", PT. Grasindo, Jakarta, 2016.

Home, James. C Van dan John Wachowicz, Jr. ; penerjemah, Quratul'ain Mubarakah, “ Prinsip-Prinsip Manajemen Keuangan" Salemba Empat, Jakarta, 2012.

Kasmir, "Analisis Laporan Keuangan", Cetakan VIII, RAJA GRAFINDO PERSADA PT, Jakarta, 2015.

Kasmir, “Analisis Laporan Keuangan”, PT. RajaGrafindo Persada, Jakarta, 2012.

Kasmir, "Pengantar Manajemen Keuangan", Cetakan V, PRENADAMEDIA GROUP, Jakarta, 2016.

Munawir, “Analisa Laporan Keuangan”, Liberty, Yogyakarta, 2014.

Munawir, “Analisis Laporan Keuangan”, Cetakan XV, Liberty, Yogyakarta, 2013.

Munawir, S, "Analisa Laporan Keuangan, Cetakan XV, Liberty, Yogyakarta, 2010.

Riyanto, Bambang, "Dasar-Dasar Pembelanjaan Perusahaan" Edisi Keempat, BPFE, Yogyakarta, 2011.

Sugiyono, "Metode Penelitian Kuantitatif Kualitatif dan R\&D", Cetakan XIII, Alfabeta, Bandung, 2011.

Sunardi, N. (2017). Determinan Kebijakan Utang Serta Implikasinya terhadap Kinerja Perusahaan (Perusahaan yang tergabung dalam indeks LQ. 45 yang terdaftar di Bursa Efek Indonesia Tahun 2011-2015). Jurnal Sekuritas, 1(1).

Sunardi, N. (2017). Pengaruh Profitabilitas, Firm Size, Risiko Bisnis, Asset Growth, Leverage, Kebijakan Dividen Terhadap Institutional Ownership (Perusahaan Property \& Real Estate yang terdaftar di Bursa Efek Indonesia Tahun 20112014). INOVASI, 2(2).

Sunardi, N., \& Sasmita, A. S. (2019). Pengaruh Likuiditas, Leverage Dan Growth Terhadap Kinerja Industri Makanan dan Minuman Yang Tercatat Di Indonesia Stock Exchange Selama Periode Tahun 2011-2015. Jurnal Sekuritas (Saham, Ekonomi, Keuangan dan Investasi), 2(2), 81-97.

Wahyudiono, Bambang, "Mudah Membaca Laporan Keuangan", Raih Asa Sukses (Penebar Swadaya Grup), Jakarta, 2014. 